\section{Luzes e sombras de histórias tornadas visíveis no Teatro da Paz}

\author{
Por Heloisa Barbuy
}

Museu Paulista, Universidade de São Paulo (hbarbuy@usp.br)

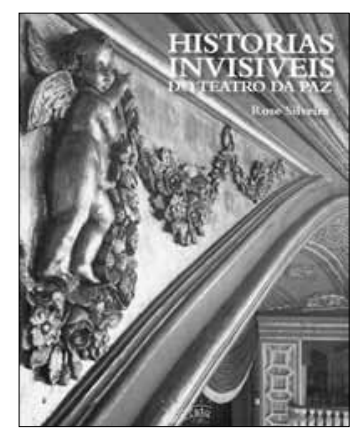

SILVEIRA, Rose

Histórias invisíveis do Teatro da Paz: da construção à primeira reforma - Belém do Grão-Pará (1869-1890) Belém: Paka-Tatu, 2010. 288 p. il. ISBN 978-857803-068-1

São tão envolventes, tão vívidas, as "Histórias invisíveis do Teatro da Paz", no modo como foram recompostas por Rose Silveira, que, ao iniciar sua leitura, mal se pode resistir à tentação de sentí-las e retê-las apenas com aquelas saudades da Belém dos tempos áureos da borracha, contra as quais a própria autora nos adverte. Afinal, o simples tema da obra nos remete, de pronto, a uma ideia inicial de belle époque, presente de tal forma no imaginário coletivo que - conta-nos a autora - uma escola de samba, tendo um enredo em homenagem ao centenário do Teatro da Paz, louvou "uma época distante e muito boa, da borracha, do champanhe e dos vitrais" (p. 42).

Rose Silveira, porém, vai muito além disso para nos proporcionar um texto preciso e sensível ao mesmo tempo, muito bem documentado e com uma interpretação compenetrada, levando-nos ao período de mais de duas décadas, decorrido entre o início da construção do Teatro, em 1869, e sua primeira reforma, realizada entre 1887 e 1890, tempo este que estava encoberto e que ela desvelou.

Engana-se também quem pensar que se trata de uma obra que fala apenas de um edifício-monumento ou de uma casa de espetáculos ou mesmo quem acreditar que só interessará a quem queira saber sobre Belém ou a província do Grão-Pará. Isto porque, ao tratar do grande teatro público da Belém imperial, Rose Silveira remete-nos a realidades e categorias que se inscrevem em quadros muito mais amplos.

O prefácio de Paulo César Garcez Marins já nos mostra bem o quanto o Teatro da Paz alinha-se a outros grandes teatros de seu tempo e pertence, como emblema, às ondas de transformações culturais e sociais que reverberavam pelo mundo a partir das principais cidades europeias, enquanto transborda de histórias particularizadas, tão bem reconstruídas pela autora. De fato, através de Belém e de seu Teatro público, Rose Silveira nos fala, em primeira instância, do século XIX, com suas mudanças regidas por um processo de internacionalização, que foi também, em grande medida, uma internacionalização cultural. E de como este processo foi realizado e vivido no Brasil, numa capital em ascensão.

Ela não o faz, porém, aplicando categorias gerais ao caso que tomou como seu objeto de estudos. Ela o faz, isto sim, pelo exame deste objeto, de forma ampla, profunda e nuançada. É por isso que consegue integrar o Teatro da Paz "à organicidade da vida na capital paraense" (p. 140). É assim que, postada em sua casa de espetáculos, ora nos camarotes de Primeira Ordem - as frisas -, ora nos de Segunda ou Terceira Ordem, ela consegue ver e examinar as políticas de 'embelezamento' urbano nas quais se inserem os planos para construção do Teatro; o ajardinamento à sua frente; a implantação de serviços de transporte; a relação entre a criação concomitante do Teatro, do Museu Paraense e da Biblioteca Pública; as 'Obras Públicas' ou a Administração Pública, enfim, como expressão de uma mentalidade e de uma filosofia de engenheiros no poder, no século XIX. E insere Belém na era das reurbanizações modernas que tiveram a Paris de Haussmann como matriz, inclusive no que diz respeito aos erros técnicos e aos desmandos financeiros.

Em outros momentos, a autora se situa na plateia ou no 'Paraíso' (a localização dos assentos mais baratos). 
É, porém, quando se instala na 'Quarta Ordem' - aquela área destinada aos que pagavam os ingressos de preços intermediários - que Rose Silveira nos revela a vida mais intensa do Teatro da Paz, manifestada por aquele "público ruidoso, irriquieto e passional, que se aboletava no último pavimento e de lá poderia tanto aplaudir quanto enxovalhar os artistas" (p. 154-155); aquele público com alguma posição social, mas inconforme às regras de etiqueta $\mathrm{e}$ ao pensamento oficial em vigor; um público visado pela repressão policial.

Na própria organização das áreas do Teatro, que correspondem a diferentes preços de ingressos e, assim, a diferentes classes sociais, a autora nos faz ver a estratificação da sociedade belenense de então. O Teatro se torna, aí, a síntese dessa sociedade.

Pela forma como examina a programação do Teatro, Rose nos remete a uma primeira fase, na qual prevalece o gosto popular ou mesmo popularesco pelas operetas e vaudevilles, números circenses, piano, canto lírico e espetáculos de ilusionismo e prestidigitação, enraizado numa cultura teatral já existente no Grão-Pará desde o século XVII. Em seguida, a autora nos mostra como o Teatro passou a apresentar, com sucesso, uma série de espetáculos afinados com o que se levava à cena nos principais teatros europeus. Aqui também ela nos está fazendo refletir sobre a internacionalização e, com esta, a autenticidade ou não dos gostos manifestos, a uma possível cultura de aparências que tantas vezes detectamos entre nós.

Em todo esse processo, a autora faz também ressaltar diante de nós figuras individuais representativas de seu tempo, como o empresário teatral pernambucano Vicente Pontes de Oliveira, que depois de alguns anos de um quase monopólio da programação do Teatro - aquela, de caráter mais popular, que agradava o público -, vê-se desbancado pelas demandas por uma programação mais refinada, que seria condizente com o novo Teatro, e que acabam levando à sua substituição na função de principal agente do Teatro da Paz, pela artista e empresária portuguesa Emília Adelaide
Pimentel. Vieram, então, àquela Casa, as óperas de Verdi, Donizetti e Carlos Gomes, entre outros espetáculos. Mas Vicente Pontes de Oliveira continuou suas atividades, num outro teatro e de outras formas, comprovando que havia público para tudo isso. Subjacentemente às histórias do Teatro da Paz, em vários momentos o livro deixa entrever toda uma vida de divertimentos populares que se dão em outros teatros ou espaços urbanos, como o Largo de Nazaré. Uma rede de lugares para os divertimentos burgueses também é abordada.

Outra figura que tem função importante na perscrutação que a autora faz daquelas realidades ocultas, que ela torna visíveis, é a do escritor José Veríssimo, a cujas crônicas ela recorre mais de uma vez para nos remeter ao tempo e lugar em questão. Em seus comentários sobre o Teatro da Paz, podemos perceber o idealismo de um homem de letras, que vê na cosmopolitização da cultura um caminho civilizador para o lugar inculto onde acredita habitar, mas que se angustia diante do que considera um despreparo da gente da terra para absorver os novos padrões culturais. É, ao mesmo tempo, um defensor dos autores nacionais que atingem esses padrões.

Uma espécie de ápice da obra se dá no terceiro capítulo, quando se chega à reforma de 1887 e aos artistas que nela atuaram, especialmente o romano Domenico de Angelis e o mulato pernambucano Chrispim do Amaral, que se tornaram parceiros fiéis e atuantes, como pintores, no Pará e no Amazonas. É que aqui a autora nos fala das pinturas alegóricas do plafond, do salão nobre, do pano de boca, dos cenários, e tudo entremeado pela instabilidade da administração pública, das argumentações técnicas, das concepções artísticas, das vidas, dos deslocamentos e das redes de relações, para nos oferecer o impacto visual propriamente dito dessas obras, que são, afinal, o grande décor que cerca o "palco como caixa mágica" (p. 210), herança do barroco com seu gosto pelo ilusionismo, a surpresa, o jogo de luzes e as sombras que são, neste livro, uma boa metáfora para as histórias brilhantemente trabalhadas por Rose Silveira.

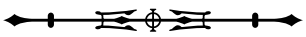

